\title{
Ritual, Folk Competitions, Mining and Stigmatization as "Poor" in Indigenous Northern Peru: A Perspective from Contemporary Quechua-Speaking Cañarenses*
}

\author{
Ritual, concursos folklóricos, minería y estigmatización como "pobres" \\ en el norte peruano indígena: una perspectiva desde los cañarenses \\ quechuahablantes contemporáneos
}

\section{JUAN JAVIER RIVERA ANDÍA}

University of Barcelona, Spain

\begin{abstract}
I explore the terms in which Cañarenses consider their unequal relationships with the world that surrounds them in the context of a transnational mining project on their lands. Both the mining industry and the Peruvian State have labeled this community as 'poor'. Based on my own fieldwork conducted between 2008 and 2011, I examine public performances of religious and cultural rituals in order to unpack the terms in which these relationships are constructed. How is fear of (and desire for) the mining project expressed? The meanings attributed to participation in (or avoidance of) these performances by the Cañarenses constitute a conceptual framework in which the label of "poverty" is being confronted. In doing so, I suggest that these Cañarenses' rituals are particularly concerned with the image of poverty used by Peruvian society to depict them. The invisibility of the Cañarenses is, in fact, what allows and even reinforces this depiction as "poor." Finally, I show that fear of the label of poverty is combined with criticism of the term itself, as used by the Peruvian State to describe the indigenous groups in its territory. How do the ritual performers define poverty? In which terms do they classify different degrees of poverty? What manifestations of poverty do they find relevant or significant?
\end{abstract}

Keywords: Andes, extractivism, indigenous peoples, Peru, mining

\section{RESUMEN}

Exploro los términos en los cuales los cañareneses consideran las relaciones desiguales con el mundo que los rodea en el contexto de un proyecto minero transnacional en sus tierras. Uno de los principales elementos es una empresa minera transnacional que, junto con el estado peruano, los califica de "pobres". Basado en mi trabajo de campo entre 2008 y 2011, examino las principales manifestaciones públicas (como rituales religiosos y competencias folklóricas) para desvelar los términos en los cuales se consideran estas relaciones. ¿Cómo se expresan el miedo y el deseo hacia el proyecto minero en estas manifestaciones locales? Los significados que se le dan a la participación o a evitar la participación en estas manifestaciones de los cañarenses constituyen un marco conceptual donde se confronta la etiqueta de "pobreza". Sugiero que estos rituales están particularmente enfocados a la imagen de pobreza con la que la sociedad peruana los ve. La invisibilidad de los cañaraneses (que describiré) es lo 
que permite y refuerza esta descripción como "pobres". Finalmente, muestro que el miedo a ser etiquetados como pobres no sólo se expresa en los rituales locales, sino que también es comentado por ellos. Estas manifestaciones contienen un comentario indígena acerca de la etiqueta de pobreza usada por el estado peruano para describir a sus grupos étnicos. ¿Cómo definen los manifestantes la pobreza? Cómo clasifican diferentes tipos de pobreza? ¿Qué manifestaciones de pobreza consideran relevantes?

Palabras clave: Andes, extractivismo, grupos indígenas, Perú, industria minera

\section{INTRODUCTION}

I explore the terms in which the Cañarenses consider their unequal relationships with the world that surrounds them and their lands. One of the main elements of this world is a Peruvian society that labels them as "poor." Based on my own fieldwork conducted between 2008 and 2011, I examine public performances of religious and cultural rituals in order to unpack the terms in which these relationships are constructed. How is fear expressed in local performances? The meanings attributed to participation in (or avoidance of) these performances by the Cañarenses constitute a conceptual framework in which the label of "poverty" is being contested. In doing so, I suggest that these Cañarenses rituals are particularly concerned with the image of poverty used by Peruvian society to depict them. The invisibility of the Cañarenses is, in fact, what allows and even reinforces this depiction as "poor." Finally, I will show that fear of the label of poverty is combined with criticism of the term itself, as used by the Peruvian state to describe the ethnic groups in its territory. How do the ritual performers define poverty? In which terms do they classify different degrees of poverty? What manifestations of poverty do they find relevant or significant? ${ }^{1}$

In previous works, I have explored how certain indigenous rituals (called herranzas) have helped to overcome the widespread fear of non-human Andean entities (usually known as "mountain spirits") (Rivera 2003, 2005). Nevertheless, I suggest that this fear is simultaneously related to a strong interest in "otherness." Some scholars have noted that this interest actually locates otherness at the core of identity (de la Torre 1986; Ortiz 1999; Pitarch 2003). That being said, my previous ethnographic research finds that some rituals confront not only a fear directed of ancient cosmological entities, but also a fear of current contemporary social problems. For example, indigenous cattle-branding rituals are clearly structured around the fear of the spirits of the mountains with whom

\footnotetext{
The case to be described here is presented only as ethnographic material for further reflection. Therefore, any potential to derive normative implications and specific forms of operationalizing the key differences stressed here remains beyond the goals of this article (and certainly the capacity of its author). The apparent modesty of the goal of this article might be better understood in terms of current anthropological debates on the politics of ontology: "Do not explain too much, do not try to actualize the possibilities immanent to others' thought, but endeavor to sustain them as possible indefinitely (this is what 'permanent' means in the phrase, 'permanent decolonization of thought'), neither dismissing them as the fantasies of others, nor by fantasizing that they may gain the same reality for oneself" (Holbraad et al. 2014).
} 
farmers have to dispute ownership of cattle. Nevertheless, at the same time, this ritual is used by the same indigenous farmers to express their concerns of their integration into national Peruvian society and its modernity (Rivera 2005).

So far, most of the published works that deal with such rituals have focused on either a particular region (e.g. the southern Andes of Peru) or only a certain perspective (e.g. their cosmological and religious aspects). ${ }^{2}$ Here, I intend to approach northern Andean indigenous rituals and recent contemporary social processes related to the image of poverty, both of which constitute underrepresented topics in current Andean studies (Fernández 2010; Rivera 2012). In doing so, I offer not only an ethnographic case from an under-studied region (Rivera 2013), but a complementary perspective on the study of Andean rituals as cultural platforms through which contemporary fears are expressed. How do northern Andean indigenous rituals do this? In what follows, I describe two different performances that position their participants in respect to their fear of the label of poverty that is currently attached to them by national authorities, particularly the Ministerio de Energía y Minas (2013).

I begin by providing a basic background about the Cañarenses of Peru that could explain their particular place (or lack of it) in the Andean region. Cañaris is located in the Lambayeque highlands. The altitude in this area extends from $1000 \mathrm{~m}$ to $4000 \mathrm{~m}$ above sea level and covers both the eastern and western slopes of the Andes. The Cañarenses inhabit the frontier between the departments of Lambayeque, Piura, and Cajamarca. Most are illiterate peasants organised in comunidades campesinas (formerly called comunidades indigenas) in the districts of Cañaris, Incahuasi, and Salas, and in the province of Ferreñafe (department of Lambayeque, northern Peruvian highlands). Despite their common identity, the Cañarenses-a population of 28,000 people-are divided by several different political boundaries. As a result, the political and economic centres of the districts to which the Cañarenses are attached are far away and difficult to reach for many members (INEI 2008, 2010).

What elements define Cañaris as a cultural area? The first and most obvious factor is the Cañaris Quechua language. Other shared characteristics in the Cañaris area-which are shared by all Cañarense communities, irrespective of political boundaries - include a specific aesthetic that is particularly evident in women's dress, shamanism associated with the use of a hallucinogenic cactus, and the use of certain rituals and handmade musical instruments, some of which are endemic (Rivera 2012, 2013; Rivera and Snowdon 2013). 


\section{THE "INVISIBILITY" OF THE NORTHERN ANDEAN INDIGENOUS PEOPLE}

Apart of the features mentioned above, Cañarenses could also be defined by what distinguishes them from other Andean regions: the strength of the indigenous language (Chirinos 2001; Escobar 2011; Howard 2011) and the absence of coca leaf production and consumption (which is emblematic of many indigenous groups in Peru). Nor is there a strong cult dedicated to the spirits of the mountains (called apus in the South of Peru) or any allusion to the notion of Pachamama (usually translated as "mother earth" in the South). In addition, the political violence associated with the "war" between the Peruvian army and "terrorist" organisations like the Shining Path (Sendero Luminoso) which disproportionately affected Quechua-speaking peasants elsewhere (CVR 2003) - has been mostly absent in the region. Finally, few Cañarenses seem to remember the local social hierarchies associated with past tensions between peasants and haciendas from the time before the agrarian reform of Peru (Ramírez 1991).

There is one more characteristic that (though paradoxically) clearly defines the Cañaris area: "invisibility." Quechua-speaking people are a minority in all the Andean countries. As in many other regions of Peru, the majority of the population of Lambayeque lives on the lowland coast, not in the highlands. Moreover, the regional centres of political and economic power are also in the lowlands. The provincial capitals with which the Cañaris lands are associated are also located on the coast, a few kilometres away from each other (Lambayeque and Ferreñafe), and quite well linked to Chiclayo (the department's capital). However, the situation is completely different with respect to the most important towns of the Lambayeque highlands. In fact, there is no road that allows direct transit by any kind of vehicle between Cañaris, Incahuasi, and Penachí-the main towns of the territory in which the Cañarenses live. As a result, these towns can only be accessed by roads that connect them with places located in different provinces and even in different departments: either from the east lowlands (in Cajamarca), or from the west lowlands (in Lambayeque). Given this situation, in Chiclayo - the political centre of the whole department of Lambayequenews coming from Lima or even from abroad is much more readily available than information from the inaccessible corners of the same political district, in particular the highlands where the Cañarenses live. Accordingly, little is known about the highlanders even though some of their main towns are just three hours' travel from Chiclayo. In fact, very few Peruvians-including those from the north-would include Lambayeque among those regions where indigenous people live and where Quechua is spoken every day. Instead, the department of Lambayeque is typically depicted as a landscape with wide coastal deserts in which there are some spectacular archaeological sites, traditional ceramics, and a diverse gastronomy based on seafood. 
This invisibility of the Cañarenses is not limited to the national society that surrounds them, but also extends to academic research on Amerindian societies, particularly Andean studies. It is worth briefly mentioning a couple of reasons behind this lack of academic concern. The first relates to the fact that the indigenismo (one of the key movements behind the emergence of Anthropology in Peru) has traditionally focused on the indigenous populations of the southern regions of the Andes (around the Cuzco axis). In contrast, studies of the northern part of the Peruvian Andes have been not only less frequent, but also much less debated by the community of Americanists. In the specific case of the Lambayeque department, the scientific research that has been done here is almost exclusively concerned with the archaeology of pre-Columbian sites, which corresponds to the deep mark left by recent archaeological findings in the reformulation of regional identities in Lambayeque (Asensio 2012).

Of the few studies that have examined the indigenous communities of northern Peru, several important contributions stand out. First and foremost are studies about the "relict forest" of the Lambayeque highlands. ${ }^{3}$ Second, several ethnographies on witchcraft (Sharon 1980; Skillman 1990)-a practice found both in the highlands and lowlands-have been publicized and even politicized in recent years. Third, there are some short and dispersed descriptions on oral tradition, religious rituals and local technologies (Vreeland 1987, 1993; Alva 1995, 2008; Gamonal 2010). Fourth, there is a group of studies interested in the indigenous language of the Cañaris (Torero 1968; Taylor 1982, 2005; Shaver 1992). The small number and limited distribution of these studies reflect the particular "invisibility" of the Cañarenses. Despite the fact that this Quechua dialect has received particular attention from linguists, Quechua-speaking Cañarenses still lack representation even among those organisations that have the indigenous languages of Peru at the core of their interests. For example, the Ministry of Culture of Peru was still unsuccessfully trying to contact Quechuaspeakers of Cañaris for the fifth edition of a subsidised translation course for indigenous languages (Ministerio de Cultura 2012). Therefore, taking into account the scientific studies of their language, the above-mentioned lack of representation actually shows the pervasiveness of their invisibility. Finally, there are brief references from historians about an ethnic group called Cañar (once located in what is today the province of Cañar, in Ecuador) displaced by the Incas to different parts of their empire. Based on some Spanish chronicles and the names of local places, an historical affiliation-which does not seem to be of much interest to the Cañarenses-has been suggested but has not yet been proven by archaeological, linguistic, ethnographic, or historic data ${ }^{4}$.

In conclusion, the almost complete absence of scientific information about the Lambayeque highlands seems to have prevented the Cañarenses from being

Actually, the cultural and social particularities of the Cañarenses mentioned above seem to have a parallel in the domain of ecology and the environment (Weigend 2002, 2004a and 2004b; Henning et al. 2009).

I have not found more than four works that explicitly look at comparisons between the south of Ecuador and the north of Peru: Renard-Casevitz et al. (1988) on historical topics; Hocquenghem et al. (1999) on sociologi- 
included in current debates about Andean societies. As don José Gaspar Lucero, a Cañarense who works as a peasant but has also been trained as a school teacher, said to me when we met for the first time (on 22 May 2008):

This is what we are worried about. Many, many of the customs here in our community have been lost. Lost! It's more useful if I beg of you-I don't know how you are going to carry out your work-to find some information ... But we would like to broadcast this, with all your equipment, when we are ready ... So that you can say, "Look at what these people have"' We want to show our customs, our identity to the world. That's our idea: to generate tourism in the village. If we, as homeowners, do not do that now, our identity will be lost in our village.

Don José Gaspar Lucero has recently formed his own political party to participate in local elections. One of the main objectives of his party-called Pulla Kañarispaq (together for Cañaris) — is to address the fear of losing their traditions that some Cañarenses feel. For José Gaspar, the invisibility they are forced to experience seems to be translated into the possibility of a complete disappearance of what they consider their traditions.

It might be important to highlight here that both Cañarenses' invisibility and stigmatization as poor are concurrent and partially overlapping processes, rather than simultaneous opposite movements. Cañarenses (i.e., their language, their cosmology, and their politics) have been historically ignored both by the state and the wider Peruvian society-until their land became profitable in the current context of neoliberal extractivism. It is only in recent years that their invisibility has been replaced by the stigma of poverty (along with two others that although related I do discuss here: the labels of "traditional" and of "terrorist") in order to legitimize the Peruvian state's interests in the region.

\section{A LABEL OF POVERTY BY THE PERUVIAN STATE}

In this context of national and academic "invisibility," the only form in which the Cañarenses seem to be visible (as happens with indigenous peoples from other regions) is through the label of "poverty" (Eversole et al. 2005). This section shows how the term is used politically and symbolically in the case of the Cañarenses. First, I discuss the way in which Peruvian national society uses the label of "poverty" as a way to continue ignoring the rights of the Cañarenses as an indigenous group. This has been the case particularly after their protests against a multinational mining company operating in their lands and against the denial of their rights as an indigenous group to be consulted about this project (de Echave et al. 2009). 
The attitude in the area towards foreign people (called gringos, in contrast to "Peruvians like us") seems to have been affected by the long-term activities (in the town of Incahuasi) of the Summer Institute of Linguistics (SIL), a wellknown faith-based non-profit organisation working in different indigenous areas worldwide. One of the few Cañarenses trained as a school teacher (who was interested in my activities as an anthropologist in her town) spontaneously told me on 20 May 2009:

Probably, its school teachers [those of the town of Incahuasi] are better connected to the city, to the television, maybe they promote more, they connect more, but here it is not like that ... But if you have come here, let's do it well, we are going to try to support you... so you can do your work, but please do not let it disappear. They do it all the time. Ah, someone comes saying "I am from such and such institutions" and later on he and his work disappear. And they do not leave anything. So where is this culture? Where is this booklet? Where is this book? At least a photocopy... I know that it costs money.

For example, now if you would say: "I promise you to..." Then I as a school teacher would reserve exclusively for you a bookshelf in order to have them there for the Cañarenses. "Look at these studies, you teachers read, you boys read, and you comuneros read!" I would tell them that. There should be a library, but there is none. At least, there should be a small place where all the customs are joined...

I am glad that you, as a Peruvian, research here. Do not allow that a gringo comes to do the research instead. They have done so in Incahuasi. But what did they do? Where are the results? There is nothing left for us! Then, what we would like is that a Peruvian comes to research so we can feel our culture to be valuable.

This native teacher's statement is clearly centred on the idea of how foreigners (and also, although somehow less outrageously, non-indigenous Peruvians) are taking something that belongs to the Cañarenses without giving anything in return. Some other Cañarenses have confirmed to me this perspective through narratives that, for example, accused the members of the SIL of stealing a golden bell from a sort of sacred tree. These narratives of deprivation are also present in the problems associated with the label of poverty.

In the following pages, I will explore the indigenous Cañarenses' perspectives on this label of poverty. One of the main consequences of being attached to this label is that it tends to overshadow their rights as an indigenous group in Peru (Merino 2012; Hallazi 2013). This is the main reason why the Cañarenses fear and try to avoid this label. How is this fear expressed and processed? I suggest that their main public performances (religious rituals and folk competitions) illustrate two contrasting but complementary cultural strategies to deal with the label of poverty that is being imposed on them by the Peruvian national society and state. One strategy is to embed this fear in a religious network in which land ownership and agricultural work are claimed as the most important 
sources of wealth. The other strategy in order to reject this label of poverty is the following: claiming to have (a relative) access to its opposite, i.e. monetary richness. I will show here how Cañaris' religious rituals follow the first strategy while the second one is performed in folk competitions.

What do the national and regional authorities mean when they define Cañarenses as illustrative of poverty in Peru? Following the first protests of the Cañarenses against the mining company established on their lands, the Minister of Energy and Mining in Peru gave a television interview (in January 2013) in which he defined them as "one of the ten poorest districts of Peru." During the same interview, he added almost immediately: "here 51\% are extremely poor, they gain less than five soles ${ }^{5}$ per day, $50 \%$ of women are illiterate, $60 \%$ have no access to water" (Ministerio de Energía y Minas 2013). The Minister was summarizing his impression of Peruvian census data from 1997. In fact, the narrative exposed by this television interview was composed of three main elements that were put as strongly related to each other: difficult access to water, inability to read, and "monetary poverty" (Ministerio de Economía y Finanzas $\mathrm{n} / \mathrm{d}$ ). These three characteristics joined here in a brief statement are used by the Peruvian national government when defining or approaching the Cañarenses. In consequence, they could be taken as the main constitutive elements of the "label of poverty" in the Cañaris case (what happens in other cases and regions remains to be studied through comparison).

It is interesting to note that this was probably the first time in the modern history of Peru that a national authority has said anything about the Cañarenses. This is obviously one of the consequences of their decision to commence a public protest and close the main road used by the multinational mining company to enter their lands. This action was taken after a gradual deterioration of the relationship between the mining company and the peasant community over the past couple of years. And this deterioration was possible in a context in which national and regional authorities-including the Oficina nacional de diálogo y sostenibilidad — did not seem to make much effort to listen to both sides "equally."

As I have already stated, I am not going to explore here this quite new critical juncture associated with the presence of a mining company. Nevertheless, it is important to point out that this first public depiction of their condition is actually inaccurate since it exaggerates the condition of poverty of the region where the Cañarenses live. ${ }^{6}$ In the past few years, the departamento of Lambayeque has ranked as the seventh-poorest in Peru. This rate of poverty is almost the same as the national rate, which is $40 \%$ of the population. If we take a closer look at its rate of "extreme poverty," it is only half of the national rate: 7\%. As a matter of fact, the scenario is not as dramatic as in other areas of Peru. Despite this, the

The amount of 5 soles is equal to $€ 1.4$ (as at 3 February 2013).

Besides, this description of the Cañarenses as "poor" corresponds to the suspicion Peruvian authorities have about the Cañarenses being misled and influenced by "radical" foreign movements (Ministerio de Energía y Minas 2013). 
reduction of poverty in Lambayeque has been less successful than the average process in the country (BCR 2008).

That being said, we should now explore a more regional context. The concept of inequality might be more helpful than poverty to understand the situation of the Cañarenses; the districts in which their main towns are located (Incahuasi, Salas, and Cañaris) are among the poorest districts of the department of Lambayeque (INEI 2010). ${ }^{7}$ Access to state services is almost absent: police have a very limited presence in the region, formal education is limited, and medical services are scarce and distrusted. In order to illustrate the unequal access to these services between the coast and the "sierra," let us consider only one example: while illiteracy affects around $10 \%$ of the population of the whole province of Ferreñafe (most of whom live on the coast), in Cañaris and Incahuasi (its highlands) almost $40 \%$ of inhabitants are illiterate (INEI 2008).

As mentioned in the introduction to this paper, there are actually two expressions of fear that could be compared: one comes from outside the community (i.e., from Peruvian society and authorities), and the other is rooted in the community itself. What I am proposing to explore here, in some detail, is the latter, although none of these reciprocal fears seem to be fully understandable without at least some fundamental contrast with the other. How does a group that has remained "invisible" under unequal relations with a national society that labelled it as "poor" actually perceive and face its situation on its own terms? I suggest that the fear attached to their invisibility and the consequences of the imposition of the label of "poor" (i.e., the denial of their rights as an indigenous group in the context of a multinational mining project) is being transferred to, or at least mirrored in, a local domain. Cañarense rituals express the fear of poverty in a double form (embedding poverty in a network in which land ownership and agricultural work are claimed as sources of wealth, or rejecting it by claiming its opposite, "monetary richness"). Additionally, they also make a collective nonverbal comment on (and evaluation of) it (Geertz 1973). Through their rituals, they express (in indigenous terms) their own perspective on this fear of poverty. This goal raises some questions that could help examine the Cañarenses' fear of the political and economic consequences of the imposition of the label of poverty. The fear of poverty among the Cañarenses is then situated in the realm of stigmatisation. They recognise this label of being "poor" in the discourses, speeches, documents, and advertising of governmental agencies (hospitals, schools, police stations), of the media, and even of non-governmental organisations.

What is poverty for them? What manifestations of poverty do they find relevant or significant? In what terms do they see and classify different degrees of poverty? For the Cañarenses, the ideas of absolute poverty and richness are, in 
fact, as rare as their manifestations. In the various versions of Quechua found all along the Peruvian Andes, the closest concept to labeling an individual as "poor" is waqcha, which can also be translated as orphan, or, more generally, as someone without relatives (Quesada 1976; Taylor 1996). Therefore, a Cañarense in his town could be considered as absolutely poor only if he or she completely lacks social ties and relatives, which is unusual in the endogamous and moreor-less closed groups of the Lambayeque highlands.

Suffering poverty is usually illustrated by the Cañarenses (and various other Quechua-speaking Andean groups) as residing or working in a very particular place: the qallka or the highest part of the mountain where agriculture is no longer possible. Qallka residents are therefore depicted as rustic herders called llakwash, and are stereotypically considered as poor outsiders (Duviols 1974).

More or less the same seems to happen in the other extreme: richness has clear limitations in societies with strong mechanisms of redistribution that are typical of Andean communities (Alberti and Mayer 1974). In consequence, as I will try to explain in the next section, both rituals' and folk competitions' comments deal in the Cañaris case with forms of poverty and richness that are much less radical than those found in, for example, the Peruvian urban world.

\section{INDIGENOUS RITUALS DEALING WITH THE LABEL OF POVERTY}

I will look now into certain local, public practices as cultural scenarios where the Cañarenses show their fear of some constitutive elements of poverty. The practices where this label (along with that of richness) is demonstrated and identified are religious rituals and folk competitions. Actually, it is in the relationship established between both performances that the fear of poverty among the Cañarenses becomes visible, or, more precisely, "enacted." Consequently, these performances make fear of poverty susceptible to collective reflection for the Cañarenses. Thus, through their public performances they become able to criticise the label of poverty that has been imposed on them.

Over the past decade, important research about the links between music, ritual, ethnic identities, and shifting social status in the Peruvian Andes has been accomplished (Romero 2001; Cánepa 2008; Mendoza 2008). Although the relevance of this academic literature is undeniable, categories like indio, señor, or mestizo do not seem to have the same relevance in daily use among the Cañarenses as in the Southern areas where most of those studies are based.

There is also considerable research on the troubled views of indigenous peasants in relation to their access to urban and national spheres. One of the founding investigations on these issues was a long-term project that compared different Quechua-speaking peasant communities of the same region from the early sixties until the early eighties. One of the main hypotheses of these authors 
was that members of the indigenous communities facing Peruvian modernity had broadly two options. The first was to leave the community and to migrate to the city, where they would become proletarians (which was supposedly the most likely choice for those with not enough land to stay in the community). The second option was to stay and transform the community, adopting capitalist logic and free market rules (which was considered the most likely choice for those with enough land to stay). In sum, according to this research, indigenous communities should either become enterprises or stay "structurally disintegrated" and "dependent" (Degregori et al. 1973; Fuenzalida et al. 1982). While a farming community was considered a prototype of the first option, a cattle-raising community was taken as a paradigmatic example of the second option.

After conducting fieldwork in the same Quechua-speaking region a decade-anda-half later (Rivera 2005), it seemed that the cattle-raising communities became neither capitalist enterprises nor "disintegrated and dependent." This was first suggested to me by contemporary pastoral rituals (celebrated at least since the sixties), which made visible the strength and cohesion of an economicallypowerful majority whose wealth was based on community-administrated resources (Rivera 2003). After analysing a hereto untapped ethnographic archive ignored so far (Rivera and Vivanco 2012), I suggested that previous scholars were considering indigenous rituals in this region as "remnants" of a "traditional culture" in modern times. On the contrary, indigenous rituals were actually key stages for precisely understanding problems like the access to modernity. In the case of Cañaris, I suggest that fear of the stigma of poverty is being ritually contested as a reaction motivated by the use of (and dissemination by) Peruvian National authorities of this label (among others). In short, this label was used to depict some of the main obstacles for contemporary Andean indigenous communities to access modernity. ${ }^{8}$

Taking into account this previous experience, I would now like to give some insights into the local perspectives of the Cañarenses, considering their main religious rituals not as a remnant but as a key cultural scenario. The religious ritual concerned here is the main annual celebration, linked to the most venerated statue kept in the church of the town (these statues change from town to town; some represent the Virgin of Mercy, while others represent Saint John the Baptist). The celebrations of each image are the responsibility of a specific land owner of the community who inherits the right to celebrate it from one generation to the next. Let us pay some attention to the different versions of this religious ritual in the main towns of the Cañarenses.

On the legal and political status and organization of indigenous communities in Peru, see Merino (2013). In a previous version of this article (Rivera 2014), I have elaborated more on the need to pay attention to non-verbal and implicit forms of contestation (in contrast, for example, to participation in political elections) in order to seriously appreciate radically different forms of indigenous politics (Candea 2014, Rivera 2015). 
In the town of Incahuasi, which is also the capital of a district of the same name, the same ritual is dedicated to a female image, the Virgin of Mercy. It is not the official eponymous icon of the town, which is in fact San Pablo. Nevertheless, while Saint Paul has only a marginal place in the annual ritual cycle, "Our Lady of Mercy" is undoubtedly the most venerated. Hence, instead of a split, here we find a substitution of the official male patron for a female image that replaces the main celebration. In the town of Cañaris, which also is the capital of a district of the same name, this ritual is dedicated to a male image, Saint John the Baptist, who is the official eponymous image of town and by far the most venerated. But in fact, San Juan is split into two images that have slightly different prerogatives and powers. One is called the Whyte One or the Big One, the other is called the Indian One (indiecito) or the Little One (San Juan Chico) and is considered to have an extraordinary power to cure the illnesses of Cañarenses.

Despite their differences, participants in the rituals performed in Cañaris and Incahuasi are considered to correspond to the label of "poor" (defined by Peruvian national society in monetary and commodity terms), as they reclaim the dependency of their livelihood to work on the land. It is important to point out that this claim corresponds to one of the most important objectives of this ritual: improved land and cattle fertility. In Cañaris, Saint John is strongly associated not only with healing but overall with water. Ritual participants devoutly moisten their hair and napes with the water taken from the marsh where Saint John (in the arms of the main celebrant who is partially immersed in the water) turns around three times at dawn. They also collect this water and bring it to their land and give it to their animals. In Incahuasi, ritual participants leave fleece from their livestock after kneeling, praying, lighting a candle and giving a monetary donation to the Virgin of Mercy. In doing so, they assure the fertility and health of their animals.

The dynamics and goals of these rituals intend to contest the label of poverty as the predominance of agriculture over other forms of livelihood. The main reason for this usual translation of the label of poverty is the prevalence of reciprocity and exchange of services over monetary payments in a context in which commodities and money are increasingly important. The Cañarenses, whose wealth mainly depends on land tenure, agriculture, and reciprocal exchanges of labour and services, are not able to access the world of Peruvian national society in the same way as are those who have a highly monetized form of livelihood (Degregori et al. 1973; Fuenzalida et al. 1982). The correspondence between work on the land and the label of poverty needs to be avoided by the Cañarenses who participate in this ritual. The fear of it is rooted in the use of the stigmatisation of poverty to deprive the Cañarenses of their rights to be consulted about the current multinational mining project in their lands as indigenous people.

A couple of years after I had concluded my fieldwork, the Coordinadora Nacional de Derechos Humanos (CNDDHH 2013) released a video in which the leader of the Cañarenses, don Cristóbal Barrios, gives a public speech in Cañaris 
town. Cristóbal addresses his listeners as "Andean indigenous people," an identification that was absent in Cañaris before 2011:

We the native people, that work the land every day, and who continue the customs of our ancestors, we are defending the immense rainforest of Lambayeque that belongs to us as a native people.

The clean waters of the Cañariaco river and of the other valleys, they belong to us. They are like the blood in our veins. That's why the Andean indigenous people-the men, the children, and the peasants-have united to say: "It's enough!" We are native peoples, and as native peoples we know our rights and duties. And for that reason, too, we have risen up to protest, to let the government and the corrupt authorities knowthey who want to invade our lands, and treat us worse than animals-we are human beings too, and we have the same rights and duties as all Peruvian citizens.

Reacting to the threats configured by these links between agricultural work, the label of poverty, and the denial of their rights, the rituals and contests (to be described in the next section) of the towns of Cañaris and Incahuasi embed their participants' fear in a religious complex in which, on the contrary, land ownership and exchanges of labour and services are claimed as the most important sources of wealth. Therefore, instead of accepting the externally ascribed status of "poor peasants," the Cañarenses stress and reassert the need to increase the fertility of their land and livestock. In sum, on the one hand, being poor is being discursively labelled by Peruvian national society as being attached to the land. On the other hand, being poor is instead corporally (i.e., ritually and non-verbally) equated by the Cañarenses to precisely being deprived of land (i.e., as not having enough crops or enough cattle).

As I will show in the next section, there is still another local form of dealing with the label of poverty and the fear of its consequences. I refer now to folk competitions that actually take place at the same time and (somehow paradoxically) compete for almost the same spaces used by the religious rituals described above.

\section{FOLK COMPETITIONS AND THE DISCLAIMING OF POVERTY: CONFRONTATIONS AND DISREGARD}

Before continuing, it might be worth more detail on the kind of perspective I am using here. This approach takes both folk competitions and religious rituals as cultural scenarios where a group reflects on current issues that affect their society. Moreover, I propose that this reflection is made more collectively than individually, and more through embodied practices than narrative discourses (Molinié 2004). 
Both in Incahuasi and Cañaris towns, the main annual religious ritual is now accompanied by a folk festival that is independently organised by municipal authorities using their external funding. Since the seventies, the people of Incahuasi have held a regular folk festival, originally created by a group of rural schoolteachers-some of them born in Incahuasi but educated in cities-most probably under the influence of the Peruvian nationalistic ideology of those years, which in Northern Peru reacted against the geographical proximity and cultural influence (mainly through radio stations) of the Republic of Ecuador. This festival-called Inkawasi Takin-has been financially supported by the municipality, while religious rituals are not funded by public money but by the wealth of private families (it should be remembered that while the logic of the folk competitions implies a winner, rituals rather pre-suppose a sponsor). Nowadays, its nationalism seems mixed with the promotion of urban and "Latin American" rhythms and musical instruments-quite different from the local indigenous musical instruments played during religious rituals (Carrasco 2013).

The history of this particular folk competition, and its local replications for the understanding of the cultural development of the Cañaris people, should not be underestimated. Since the first time it was organised in the early seventies (under the political influence of the Gobierno revolucionario de las fuerzas armadas), the folkloric festival has increased its number of participants, funding, and duration and has also been replicated in other towns of the Cañarenses. Nowadays, in the town of Cañaris, a similar folkloric festival is also organised by the municipality and a Catholic order founded by a German priest and present in some of the most isolated places of Peru (Misioneras de Jesús, verbo y victima), that are said to accept donations from the foreign mining company operating in the region. Although the Cañaris version is not as large as that of Incahuasi, the participants seem to be equally sensitive to the key messages of this festival. Those who get involved in the folk competitions do so with the hope of obtaining some of the monetary or commodity compensations offered by the organisers. Although they could be considered a sort of top-down initiative, the festivals present themselves as exposing their participants to the modernity of the urban world and consequently as releasing them from one of the most feared aspects of the label of poverty.

Let us now briefly describe the dynamics of folk competitions, contrasting them with religious rituals. With some variations between towns, folk competitions follow a similar pattern taken from the cities of the lowlands. It is quite important to note that these competitions are also folkloric spectacles of dancing, singing, and playing. Actually, the jury and the competitors are always completely surrounded by a public that does not vote but is still quite willing to publicly and loudly show their particular support. Folk competitions make constant and strong use of electrical devices (such as mp3 players, microphones, and loud-speakers). This first characteristic provides a sharp contrast with the religious rituals that have never resorted to any other devices apart from the 
local handmade musical instruments. The modernity of the urban world of the lowlands is associated with the electrical or manufactured musical instruments and with the music played by them. The second characteristic concerns the use of space. While folk competitions take place on just one main stage, the main phases of religious rituals happen in different places simultaneously or consecutively.

As has been stated before, those farmers actively engaging in religious rituals are usually considered to correspond to the label of "poor" used by national authorities and agencies. On the other hand, those who participate in folk competitions are called the "rich." With this latter term, Cañarenses describe those wealthy enough to move comfortably and frequently between the lowland cities and the highland indigenous communities. This mobility enables them to establish relatively big businesses or to monopolise political power and funding attached to a municipality (Ansión et al. 2000).

Let us consider another political aspect of the label of "poor" in the case of the Cañarenses. Those involved in rituals and contests actually belong to or support different key political organisations in the region. On the one hand, those who are directly involved in religious rituals are joined together in a group of land owners (usually called in the Andes cofradias and comunidad). All over the Andes, this organisation is the main form of political organisation for indigenous peoples-it was actually called comunidad indigena until the seventies when they changed the name to comunidad campesina (Diez 2005). On the other hand, those who participate in and support folk competitions have the municipality as their economic and political axis. The activities and power of the comunidad is mostly based on farming activities and on land tenure. Instead, the municipality depends only on funding from abroad; the national or regional governments assign them a certain amount of money each year. These differences are taken into account by the members and supporters of each organisation and permeate decision making concerning which one would be supported on what occasion. In general terms, the municipality attracts those more interested in access to the urban world of the lowlands while the comunidad joins those whose income originates from land tenure.

There is another consequence of these economic and political aspects of participation in religious rituals or folk competitions. In fact, they are performed around the same dates in the main villages of the Lambayeque highlands. This simultaneity acquires not only a sense of a tacit confrontation, but also a meaning of explicit disregard between both groups. Once a year, contest spectators and ritual participants, "rich" and "poor," shopkeepers or wage-earners and peasants, dramatize what defines them and what distinguishes them; and they do so even while occupying the same places. The religious ritual may occupy the side of the main square where the church is located. In contrast, the folk competition occupies the side of the main square with the municipal building, while its huge loud-speakers flood the surrounding space. Even in marginal ritual places like those out of the main square, this confrontation and disregard 
seems to be the rule. For example, before, during, and after the procession of Saint John in the marshes, the municipality organises football matches that take place in a stadium that is on the route taken by the participants in the ritual.

\section{FINAL CONSIDERATIONS}

Religious rituals attached to agricultural work and folk competitions supported by external funding simultaneously express (in a non-verbal form) and tame fear when constituting two contrasted groups of Cañarenses. They express the fear of the label of poverty, either reasserting the importance of symbolic protection and fertility of cattle and crops linked to land work (religious rituals) or proclaiming their monetary wealth and access to modern Peruvian national society (folk competitions). Public performances express the same fear (that of the consequences of being stigmatised as "poor") in different forms. Both deny the condition of "poor peasants," but one does it by stressing the symbolic mechanism for obtaining wealth out of land work and the other does it by boasting of monetary overspending. In this way, both public performances tame this fear through the reciprocal disregard of each group of participants. It might be important to note here that there is no direct confrontation between those participating in ritual and those in contests. Neither would it be easy to detect a conflict among Cañarenses which would be based on this division. Instead of an open confrontation, we observe a mutual disregard. While focusing only on their own collective answer to the threat they are currently facing, the religious rituals and folk competitions of Cañarense participants symbolically diminish the ideological components of their fears. Doing so, they can better face the fears linked to the external imposition of the label of poverty.

I have intended to explore the non-verbal expression of certain indigenous views of the label of poverty as it is being imposed on the Cañarenses by the Peruvian national authorities and agents in the current context of a multinational mining project to take place within their lands (Rivera \& Snowdon 2013). It would be interesting to explore whether this response to fear in the form of public performances might be restricted to this context. Unfortunately, we still have to cope with the lack of ethnography prior to the arrival of the mining company. Stigmatisation as "poor peasants" not only differs from the Cañarenses' point of view, but can also be used to deprive them of their voice as an indigenous group. Ultimately, one of the consequences of the use of this label is to delegitimise their possible participation in current negotiations on the multinational mining project. Cañarenses' public performances as folk competitions and religious rituals described here actually constitute non-verbal forms of dealing with the fear of the consequences of such a stigmatisation. This collective fear is expressed and evaluated through public performances that ascribe to their participants specific symbolic strategies, and situate them in a particular political and economic cartography. In sum, by labelling Cañarenses as merely poor peasants, the Peruvian state feeds a set of symbolic statements that tacitly 
undermine their chances to have a voice in the current mining multinational projects within their lands.

\section{REFERENCES}

Alberti, Giorgio and Enrique Mayer, eds. 1974. Reciprocidad e intercambio en los Andes. Lima: IEP.

Alva Mariñas, Pedro 1995. "Pachacamac en la serranía de Lambayeque". Utopía Norteña 2: 231-234.

Ansión, Juan, Alejandro Diez and Luis Mujica, eds. 2000. Autoridad en espacios locales: una mirada desde la antropología. Lima: PUCP.

Asensio, Raúl H. 2012. Nosotros los muchik. Turismo, arqueología, antropología y discursos de identidad colectiva en la costa norte del Perú (1987-2009). In ¿El turismo es cosa de pobres? Patrimonio cultural, pueblos indígenas y nuevas formas de turismo en América Latina, edited by Raúl H. Asensio and Beatriz Pérez Galán. Lima: IEP, 3560.

[BCR] Banco Central de Reserva del Perú. 2008. Informe Económico y Social Región Lambayeque. Lima: BCR. Retrieved from http://www.scribd.com/doc/13744443/COMPLETO-Informe-Economico-y-Social Lambayeque

Candea, Matei. 2014. "The Ontology of the Political Turn. Theorizing the Contemporary". Cultural Anthropology. Retrieved from https://culanth.org/fieldsights/469-the ontology-of-the-political-turn

Cánepa, Gisela. 2008. The Fluidity of Ethnic Identities in Peru. CRISE Working Paper 46. University of Oxford, UK. Retrieved from http://www.crise.ox.ac.uk/pubs/workingpaper46.pdf. Accessed on 10/14/2011.

Carrasco Lucero and Alfredo Leandro. 2013. Inkawasi, la singularidad de sus expresiones culturales. Ferreñafe: CIDEC.

Chirinos, Andrés. 2001. Atlas lingüístico del Perú. Cusco, Lima: Ministerio de Educación, Centro Bartolomé de las Casas.

[CNDDHH] Coordinadora Nacional de Derechos Humanos. 2013. Cañaris desde adentro. Lima: Grufides. Retrieved on 12 December 2013 from http://www.youtube.com/ watch?v=fzoe1B1y3mw

[CVR] Comisión de la Verdad y Reconciliación. 2003. Informe Final. Lima: CVR. Retrieved on 3 February 2013 from http://www.cverdad.org.pe/ifinal/index.php

de Echave, José; Alejandro Diez, Ludwig Huber, Bruno Revesz, Xavier Ricard Lanata and Martín Tanaka. 2009. Minería y conflicto social. Lima: CB, CIPCA, CIES, IEP.

Degregori, Carlos Iván and Jurgen Golte 1973. Dependencia y desintegración estructural en la comunidad de Pacaraos. Lima: IEP.

de la Torre, Ana. 1986. Los dos lados del Mundo y del Tiempo. Representaciones de la naturaleza en Cajamarca indígena. Lima: Centro de Investigación, Educación y Desarrollo.

Duviols, Pierre 1974. "Huari y llacuas; agricultores y pastores. Un dualismo prehispánico de oposición y complementariedad." Revista del Museo Nacional 39: 153-191.

Escobar, Anna Maria. 2011. "Dinámica sociolingüística y vitalidad etnolingüística: quechua y aimara peruanos del siglo XXI." In Estudios sobre lenguas andinas y amazónicas. Homenaje a Rodolfo Cerrón-Palomino, edited by W. Adelaar, P. Valenzuela, Roberto Zariquiey. Lima: PUCP, 125-145.

Eversole, Robyn, John-Andrew McNeish and Alberto D. Cimadamore, eds. 2005. Indigenous Peoples and Poverty. An International Perspective. London, New York: CROP.

Fabre, Alain. 2005. Diccionario etnolingüístico y guía bibliográfica de los pueblos indígenas sudamericanos. Quechua. Retrieved on 30 April 2013 from http://fr.scribd.com/ doc/63374875/Alain-Fabre-Bibliografia-Quechua 2013\#download

Fernández, Gerardo. 2010. “'Norte contra Sur'. Análisis comparativo sobre ofrendas rituales andinas." Revista Española de Antropología Americana 40 (1): 239-259. 
Fuenzalida, Fernando, Carlos Iván Degregori, Juvenal Casaverde, Jürgen Golte, Teresa Valiente Catter and José Luis Villarán. 1982. El desafío de Huayopampa: comuneros y empresarios. Lima: IEP.

Gamonal Guevara, Ulises. 2010. Tupay Tupana y otros relatos del Alto Marañón. Jaén: Editorial Filito.

Geertz, Clifford. 1973. The Interpretation of Cultures. New York: Basic Books.

Henning, Tilo, Asunción Cano and Weigend, Maximilian. 2009. "A new shrubby species of Nasa Weigend ser. Carunculatae (Urb. \& Gilg) Weigend (Loasaceae) from the Amotape-Huancabamba Zone." Revista Peruana de Biología 16 (2): 151-156.

Hallazi, Luis. 2013. "Perú: El caso de la Comunidad de Cañaris y el Derecho a la Consulta Previa." Servicios en comunicación intercultural (SERVINDI). Retrieved on 13 December 2013 from http://servindi.org/actualidad/81367

Hocquenghem, Anne-Marie, Lanning, Zaida, and Pierre Gondard. 1999. Contribución al conocimiento de una zona de encuentro entre los Andes ecuatorianos y peruanos. Lima: IFEA.

Holbraad, Martin, Morten Axel Pedersen and Eduardo Viveiros de Castro. 2014. "The Politics of Ontology: Anthropological Positions." Cultural Anthropology. Retrieved from https://culanth.org/fieldsights/462-the-politics-of-ontology-anthropological positions

Howard, Rosaleen. 2011. "The Quechua Language Today: Between Statistics, the State and Daily Life." In History and language in the Andes, edited Paul Heggarty and Adrian Pearce. New York: Palgrave Macmillan, 189-214.

[INEI] Instituto Nacional de Estadística de Informática. 1997. Impacto de los programas de apoyo social 1997-1998. El valor de las necesidades básicas. Lima: INEI. Retrieved on 5 February 2013 from http://www.inei.gob.pe/biblioineipub/bancopub/est/lib0383/ CAP1.htm

[INEI] Instituto Nacional de Estadística de Informática. 2008. Departamento de Lambayeque. Censos Nacionales 2007. XI de población y VI de vivienda. Vol. I. Lima: INEI.

[INEI] Instituto Nacional de Estadística de Informática. 2010. Mapa de pobreza distrital y provincial 2009. El enfoque de la pobreza monetaria. Lima: Dirección técnica de demografía e indicadores sociales.

Mendoza, Zoila. 2008. Creating our Own: Folklore, Performance, and Identity in Cuzco, Peru. Durham: Duke University Press.

Merino, Roger. 2012. "Perú: En defensa de lo comunal: cinco errores en el análisis de los conflictos socio-ambientales." Servicios en comunicación intercultural (SERVINDI). Retrieved on 13 December 2013 from http:/ / servindi.org/actualidad/65708

Merino, Roger. 2013. "Critical Human Rights and Liberal Legality: Struggling for 'The Right to Have Communal Rights.'" Philosophy Study 3 (3): 246-261.

Ministerio de Cultura. 2012. Convocatoria para el Cuarto y Quinto curso de capacitación de intérpretes de lenguas indígenas para la consulta previa. Lima: Viceministerio de Interculturalidad, Dirección General de Interculturalidad y Derechos de los Pueblos. Retrieved on 4 February 2013 from http://www.mcultura.gob.pe/sites/default/files/ docs/convocatoria_cuarto_curso_de_i terpretes.pdf

Ministerio de Economía y Finanzas. n.d. ¿Qué se entiende por pobreza monetaria?. Lima: MEF. Retrieved on 6 February 2013 from http:/ / www.mef.gob.pe/index.php?view=items\&cid=1\%3Apolitica-economica-y social\&id=399\%3A88-ique-se-entiende-por-pobreza monetaria\&option=com_quickfaq\&Itemid=100006\&lang=es

Ministerio de Energía y Minas. 2013. Ministro Merino pide unidad de peruanos para rechazar radicalismo de protestas antimineras [Interview with minister Jorge Merino Tafur]. Retrieved on 1 February 2013 from http://www.youtube.com/watch?v=JLQ4zxaIPKU\&list=FLKQC7Z oQuhMSsVzaHqRMA\&index $=4$

Molinié, Antoinette. 2004. "The Revealing Muteness of Rituals: A Psychoanalytical Approach to a Spanish Ceremony." The Journal of the Royal Anthropological Institute 10 (1): 41-61.

Olivera Núñez, Quirino, ed. 2009. Antiguas civilizaciones en la frontera de Ecuador y Perú. Una propuesta binacional para la integración andina. Asociación Amigos del Museo de Sipán. 
Ortiz Rescaniere, Alejandro. 1999. "El individuo andino, autóctono y cosmopolita." In Cultura y globalización edited by Carlos Iván Degregori and Gonzalo Portocarrero. Lima: PUCP, Universidad del Pacífico, IEP, 129-138.

Pitarch, Pedro. 2003. "Infidelidades indígenas." Revista de Occidente 269: 60-76.

Quesada, Félix. 1976. Diccionario Quechua de Cajamarca-Cañaris. Lima: Ministerio de Educación del Perú.

Ramírez, Susan. 1991. Patriarcas provinciales: La tenencia de la tierra y la economía del poder en el Perú colonial. Madrid: Alianza Editorial.

Rappaport, Roy A. 1999. Ritual and Religion in the Making of Humanity. New York: Cambridge Univerity Press.

Renard-Casevitz, France Marie, Thierry Saignes and Anne Christine Taylor. 1998. Al Este de Los Andes: relaciones entre las sociedades amazónicas y andinas entre los siglos XV y XVII. Quito: Ediciones Abya-Yala.

Rivera Andía, Juan Javier. 2003. La fiesta del ganado en el valle de Chancay. Lima: PUCP.

Rivera Andía, Juan Javier. 2005. "Killing What You Love. An Andean Cattle Branding Ritual and the Dilemmas of Modernity." Journal of Anthropological Research 61 (2): 129-156.

Rivera Andía, Juan Javier. 2012. “Un enigma etnográfico en los Andes septentrionales del Perú. Notas sobre un aerófono indígena tocado sólo por mujeres." Indiana 29: 253-272.

Rivera Andía, Juan Javier. 2013. “Una organología tradicional de los Andes septentrionales peruanos. En torno a los instrumentos musicales de la sierra de Lambayeque (distrito de Cañaris, provincia de Ferreñafe)." Anthropos 108: 463-480.

Rivera Andía, Juan Javier. 2014. "Fears and Rituals in Contemporary Northern Peruvian Andes." In The Anthropology of Fear. Cultures beyond Emotions, edited by Andrea Boscoboinik and Hana Horáková. Zürich: LIT Verlag, 101-122.

Rivera Andía, Juan Javier. 2015. "La iglesia de Incahuasi. Notas sobre antropología simétrica, arquitectura e historia en los Andes peruanos septentrionales (Ferreñafe, Lambayeque)." Revista Española de Antropología Americana 45 (2): 551-568.

Rivera Andía, Juan Javier and Peter Snowdon. 2013. The Owners of the Land. Genk: Het Vervolg. DVD + Booklet.

Rivera Andía, Juan Javier and Alejandro Vivanco. 2012. Una etnografía olvidada en los Andes. Madrid: CSIC.

Robin, Valérie 2008. Miroirs de l'autre vie. Pratiques rituelles et discours sur les morts dans les Andes de Cuzco (Pérou). Nanterre: Société d'ethnologie.

Romero, Raúl R. 2001. Debating the Past: Music, Memory, and Identity in the Andes. New York: Oxford University Press.

[SERVINDI] Servicios en Comunicación Intercultural. 2013. Los heridos de Cañaris. Agredidos en su tierra comunal por defender su modo de vida. Retrieved on 28 June 2013 from http://lamula.pe/2013/01/30/los-heridos-de-canaris-agredidos-en-su-tierra comunal-por-defender-su-modo-de-vida/Servindi/

Sharon, Douglas. 1980. El chamán de los cuatro vientos. México: Siglo Veintiuno.

Shaver, Dwight. 1992. "El quechua de Lambayeque en relación con las demás variedades quechua." In Estudios etnolingüísticos II, edited by Stephen Parker. Yarinacocha: ILV, 215-223.

Skillman, Donald. 1990. Huachumero: Peruvian Curandero Jorge Merino Bravo. R. San Diego: Museum of Man.

Taylor, Gerald. 1982. "Breve presentación de la morfología del quechua de Ferreñafe." Lexis 6 (2): 243-270.

Taylor, Gerald. 1996. El quechua de Ferreñafe: Fonología, morfología, léxico. Cajamarca: Acku Quinde.

Taylor, Gerald. 2005. "Innovaciones morfológicas en un dialecto quechua aislado: el caso de Ferreñafe." In Contribuciones a las lenguas y culturas de los Andes, edited by Sabine Dedenbach-Salazar Sáenz. Aachen: Shaker Verlag, 31-56.

Torero, Alfredo. 1968. "Procedencia Geográfica de los Dialectos Quechuas de Ferreñafe y Cajamarca." Anales Científicos de la Universidad Agraria VI (3-4): 291-316. 
Vreeland, James 1987. "La tonada del chimu en la fiesta andina de Incahuasi." Suplemento Dominical de La Industria, pp. 6. Chiclayo. 18 de octubre.

Vreeland, James. 1993. "Danzas tradicionales de la sierra de Lambayeque". In Música, danzas y máscaras en los Andes, edited Romero Raúl R. Lima: PUCP, 179-217.

Weigend, Maximilian. 2002. "Observations on the Biogeography of the Amotape Huancabamba Zone in Northern Peru." Plant Evolution and Endemism in Andean South America. Botanical Review 68 (1): 38-54.

Weigend, Maximilian. 2004a. "Four New Species of Nasa ser. Alatae (Loasaceae) in the Amotape-Huancabamba Zone of Peru." Novon 14 (1): 134-146.

Weigend, Maximilian. 2004b. "Additional Observations on the Biogeography of the Amotape-Huancabamba Zone in Northern Peru - Defining the South-Eastern limits." Revista Peruana de Biología 11 (2): 127-134.

Weigend, Maximilian, César Arana and Eric Rodríguez. 2005. "New Species and New Records of the Flora of the Amotape-Huancabamba Zone: Endemics and Biogeographic Limits". Revista Peruana de Biología 12 (2): 249-274.

Juan Javier Rivera Andía holds a doctorate in Anthropology from the Universidad Complutense de Madrid. He has taught at Peru's most important Anthropology departments and served as director of the Museo Nacional de la Cultura Peruana and the Registro y Estudio de la Cultura en el Perú Contemporáneo. He has been a visiting researcher at the Maison de Sciences de l'Homme (Paris), the Smithsonian Institution (Washington), the University of Leiden, the Katholieke Universiteit Leuven, the University of Bergen, Université Paris Ouest Nanterre La Défense, the University of Barcelona, and the Netherlands Institute for Advanced Study in the Humanities and Social Sciences (NIAS), supported by the EURIAS program. Email: jjriveraandia@gmail.com 